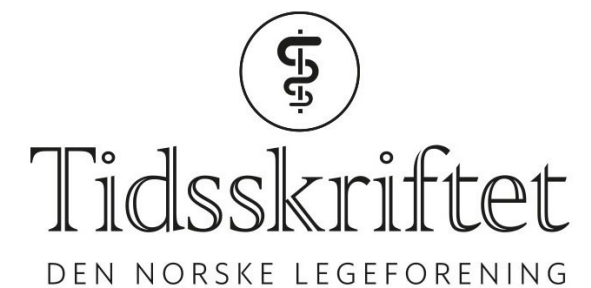

DEN NORSKE LEGEFORENING

\title{
Kvinnehelse, kjønn og trange livsrom
}

LEDER

\section{KIRSTI MALTERUD}

E-post: kirsti.malterud@gmail.com

Kirsti Malterud er spesialist i allmennmedisin, forsker 1 ved Allmennmedisinsk forskningsenhet og NORCE Norwegian Research Centre, og professor II ved Universitetet i Bergen. Forfatter har fylt ut ICMJE-skjemaet og oppgir ingen interessekonflikter.

Kjønn er mer enn biologi. En snever kjønnsforståelse kan hindre god helsehjelp.

Biologisk ulikhet har tradisjonelt vært legers grunnlag for forståelse av kjønn. Men vil vi se på helse i et kjønnsperspektiv, blir biologiske tilnærminger utilstrekkelige. Kjønn formes også gjennom identitet, symboler og strukturer (1). Kjønn som identitet handler om individets selvforståelse, slik vi ser det ved spiseforstyrrelser, depresjon og andre psykiske plager (2). Kjønn som symbol omfatter kulturens fremstillinger av mannlighet og kvinnelighet og preger blant annet forståelsen av kvinner med medisinsk uforklarte helseplager $(1,3)$. Kjønn som struktur henger sammen med fordeling av arbeid, rettigheter og innflytelse, eksempelvis makt som legitimerer vold og forskjellsbehandling av kvinner eller kjønnsforskjellige mønstre for helsetjenestebruk (4). Alle nivåene omhandler sammenhenger mellom helse, kjønn og trange livsrom. Synliggjøring av kjønnsforskjeller i sykdomsprofil, levekår og kontakt med helsetjenester var en sentral strategi for oss som engasjerte oss i medisinsk kvinneforskning på 1980-tallet. Gradvis flyttet tyngdepunktet i det internasjonale forskningsfeltet seg fra kvinner til kjønn, og fra «å være kjønn» til «å gjøre kjønn». Interseksjonalitet var et analytisk begrep som satte kjønn i sammenheng med etnisitet, klasse, seksualitet og funksjonsevne.

Samtidig var biologi fortsatt et sentralt tema. Kjønnsforskere stilte spørsmål ved den biologiske todelingen av kjønn, der tokjønnsmodellens anatomiske og fysiologiske kjennetegn var selvsagte kjønnskriterier (5). Riktignok gir denne modellen et tydelig skille mellom de fleste gutter og jenter ved fødselen og senere i livet, men det er også betydelig biologisk overlapping mellom kjønnene. Eksempelvis er ikke alle kvinner lavere enn alle menn (1), og et mindretall (i Norge cirka 1 av 20o) fødes med interkjønn - variasjoner i kroppslig kjønnsutvikling (6).

Skeiv teori (queer theory) utfordrer gjeldende forståelsesmåter for kjønn og seksualitet (7). Binære opposisjoner er begrepspar med gjensidig utelukkende motsetninger som mange oppfatter som essensielle, uforanderlige kategorier, eksempelvis mann/kvinne og heterofil/homofil. Skeiv teori stiller spørsmål når slike kategorier tas for gitt, for eksempel til å predikere samsvar mellom biologisk kjønn, kjønnsidentitet, kjønnsuttrykk og seksuell orientering. Det er ikke opplagt at et individ med penis opplever og presenterer seg som mann eller tiltrekkes av kvinner.

Personer med kjønnsinkongruens - transpersoner - opplever ubehag eller manglende 
samsvar knyttet til kjønnsidentitet eller kjønnsuttrykk og det juridiske kjønnet som ble tildelt ved fødsel (8). Noen søker kjønnskorrigerende behandling, og de fleste ønsker større aksept for et kjønnsuttrykk de kjenner seg på plass i. Etter norsk lov kan personer selv bestemme sitt juridiske kjønn, uavhengig av medisinsk status. Blant homofile, lesbiske, bifile, transpersoner og personer med interkjønn finner vi en større andel med alvorlige helseproblemer sammenlignet med majoritetsbefolkningen $(9,10)$.

Derfor må leger ta inn over seg endringer i forståelse av kjønn, slik at alle kan få best mulig helsehjelp. Mange kolleger vegrer seg mot å flytte blikket fra en tradisjonell biologisk forståelse av kjønn, der kvinner er kvinner og menn er menn. Noen oppfatter det som kontroversielt å tenke nytt om dette. Men som leger bør vi søke kunnskap hvis vi føler oss usikre eller noe fremstår som fremmed. Retningslinjer og gode ressurser finnes (11).

På legekontoret vil vi fortsatt møte kvinner med helseproblemer som medisinsk uforklarte helseplager, minoritetsstress eller overgrep. Medisinsk praksis utgjør en arena for forhandlinger om betydningen av kjønn i samfunnet (1).Vi som er leger må derfor ta ansvar for hvordan vi forstår kjønn når vi møter et mangfold av mennesker med helseplager som kan stamme fra trange livsrom.

\section{LITTERATUR:}

1. Taksdal A, Malterud K. Et felles refleksjonsrom: hypoteser om betingelser, begrensninger og utfordringer for gyldiggjøring av kvinners symptomer som medisinsk kunnskapskilde. SEFOS-notat 6-200o. Bergen: Senter for samfunnsforskning, 2000.

2. Willadsen J. Depression, dit navn er kvinde. Mandsvælde og helbred. København: Lindhardt \& Ringhof, 1983 .

3. Malterud K. The (gendered) construction of diagnosis interpretation of medical signs in women patients. Theor Med Bioeth 1999; 20: 275 - 86. [PubMed][CrossRef]

4. Hølge-Hazelton B, Malterud K. Gender in medicine - does it matter? Scand J Public Health 2009; 37: 139 - 45. [PubMed][CrossRef]

5. Fausto-Sterling A. Sexing the body: Gender politics and the construction of sexuality. New York, NY: Basic Books, 2000.

6. Diseth TH. Barn født med uklare kjønnskarakteristika. Tidsskr Nor Legeforen 20o8; 128: 576 - 8o. [PubMed]

7. Butler J. Bodies that matter. On the discursive limits of sex. London og New York, NY: Routledge, 1993.

8. Benestad EEP, Thesen J, Aars H et al. Helsevesenet svikter transpersoner. Tidsskr Nor Legeforen 2017; 137. doi: 10.4045/tidsskr.17.0422. [PubMed][CrossRef]

9. Anderssen N, Malterud K. red. Seksuell orientering og levekår. Bergen: Uni Helse, 2013. http://bora.uib.no/bitstream/handle/1956/7550/Seksuell_orientering_og_levekår.pdf(22.9.2018).

10. van der Ros J. Alskens folk. Levekår, livssituasjon og livskvalitet for personer med kjønnsidentitetstematikk. Hamar: Likestillingssenteret - Kvinneuniversitetet, 2013. https://likestillingssenteret.no/wp-content/uploads/2016/o2/Alskens-folk.pdf(22.9.2018).

11. The World Professional Association for Transgender Health (WPATH). Standarder for behandling og helseomsorg for transseksuelle, transpersoner og personer som ikke er kjønnsnormative. Versjon 7 , 2012. https://www.wpath.org/publications/soc (7.6.2018).

Publisert: 15. oktober 2018. Tidsskr Nor Legeforen. DOI: 10.4045/tidsskr.18.0715

(C) Tidsskrift for Den norske legeforening 2020. Lastet ned fra tidsskriftet.no 